\title{
Using rapid assessment of marine pollution (RAMP) techniques to assess the quality of marine sediments
}

\author{
Abessa, D.M.S. ${ }^{1, *}$; Bícego, M.C. ${ }^{2}$; Sousa, E.C.P.M. ${ }^{2}$; Zaroni, L.P ${ }^{2,3}$; \\ Rachid, B.R.F. ${ }^{2,4}$; Arnalot, E.C ${ }^{2,5}$; Fillmann, G. ${ }^{6}$; Readman, J. ${ }^{7}$ \& Depledge, M. ${ }^{8}$ \\ 1. Universidade Estadual Paulista, Campus do Litoral Paulista, 11030-160, São Vicente, SP, Brazil \\ 2. Universidade de São Paulo, Instituto Oceanográfico, 05508-900, São Paulo, SP, Brazil \\ 3.Zaroni \& Frazão. Oceanografia e Meio Ambiente, São Paulo, SP, Brazil. \\ 4. BR Ambiental, São Paulo, SP, Brazil. \\ 5. Instituto de Investigação das Pescas e do Mar, Lisboa, Portugal. \\ 6. Universidade Federal do Rio Grande, Instituto de Oceanografia, 96203-900, Rio Grande, RS, Brazil \\ 7. Plymouth Marine Laboratory, Prospect Place, West Hoe, Plymouth, PL1 3DH, UK \\ 8. European Centre for Environment and Human Health, University of Exeter Medical School, Truro, Cornwall, TR1 3HD, UK.
}

Received December 15, 2017; Accept July 13, 2018

\begin{abstract}
Sediments represent an important environmental compartment, because they provide substrate for a range of species and may accumulate contaminants in high concentrations. However, the universe of methods to assess the quality of sediments is still small. This investigation aimed to assess the quality of sediments from some sites of Ubatuba (SE Brazil). To achieve that, sediments were analyzed for the presence of PAHs, by immunoassay ELISA kit for the carcinogenic PAH (c-PAH) RaPID Assay, and for toxicity to amphipods, sea-urchin embryos and direct exposure of mussel hemocytes and measurements of the nuetral red retention time (NRTT). Results showed higher levels of PAHs in sediments from Itagua and Ribeira, those more intensely affected by contamination sources. The ecotoxicological analyses indicated these two sites as more degraded, together with the sediments from Lamberto Beach, which is also influenced by nautical activities. The NRRT correlated with the quantities of PAHs in sediments. We concluded that Ribeira Bay and Itaguá Beach need more detailed investigation on pollution and that the NRRT assay exposing directly hemocytes to sediment elutriates can be a useful tool to assessing sediment quality.
\end{abstract}

Keywords: coastal zone, contamination, toxicity, neutral red retention time, biomonitoring; early warning.

\section{INTRODUCTION}

Sediments are an important compartment of marine and estuarine ecosystems, providing substrate, food and shelter to a large number of benthic and epibenthic species (Abessa et al., 2006). However, sediments are also subjected to anthropic influences, because they consist of repositories for many of contaminants that are discharged in the aquatic systems (Swartz et al., 1985). Once in the sediments, contaminants may accumulate or be transformed by chemical and biological processes, may be assimilated by benthic organisms or released to the water column and may cause toxic effects to the aquatic biota (Nipper et al., 1989).

Despite the ecological importance, not many techniques are available for assessing the quality of estuarine and marine sediments. The available approaches comprise chemical analyses, toxicity tests, bioaccumulation assays, and the analysis of the benthic community structure (Chapman \& Hollert, 
2006); however, the number of biological models to evaluate the toxicity of sediments is quite small, especially in tropical environments. Although Brazil has a coastline of about 8,000 $\mathrm{km}$ sediment quality assessments have been conducted with less than 10 species, including embryos of the sea urchins Lytechinus variegatus and Echinometra lucunter (ABNT, 2012), amphipods Tiburonella viscana (ABNT, 2008; Melo $\&$ Abessa, 2002) and Grandierellla bonnieroides (Molisani et al., 2013), tanaid Kalliapseudes schubartii (Zamboni \& Costa, 2002), copepods Nitocra sp (Lotufo \& Abessa, 2002) and Tisbe biminiensis (Araújo-Castro et al., 2009), shrimp juveniles (Nascimento \& Evangelista, 2002) and the clam Anomalocardia flexuosa (Cruz, 2014). Thus, a much thorough ecotoxicological approach is urgently needed to better assess the sediment quality.

An additional aspect of tropical and subtropical regions is the scarcity of previous information about the studied area.
Thus, contaminants levels and risks to the biota are often unknown. In these cases, screening techniques can used to identify hot spots and thus indicate priority sites where further studies should be conducted (Galloway et al., 2002). Such screening techniques should be rapid and cost effective allowing them to be used as the first step of tiered approaches, so that if the analysis of the initial set of data confirms the potential contamination, more thorough, reliable, and consequently expensive and time-consuming methods can be employed along this specific area.

Initial investigations of sediment quality have employed sediment toxicity tests, which are considered sensitive and provide reliable information on the sediment quality (Abessa et al., 2006). These techniques, however, may present some limitations, especially because they may not be sufficiently rapid in providing environmental information. Some studies
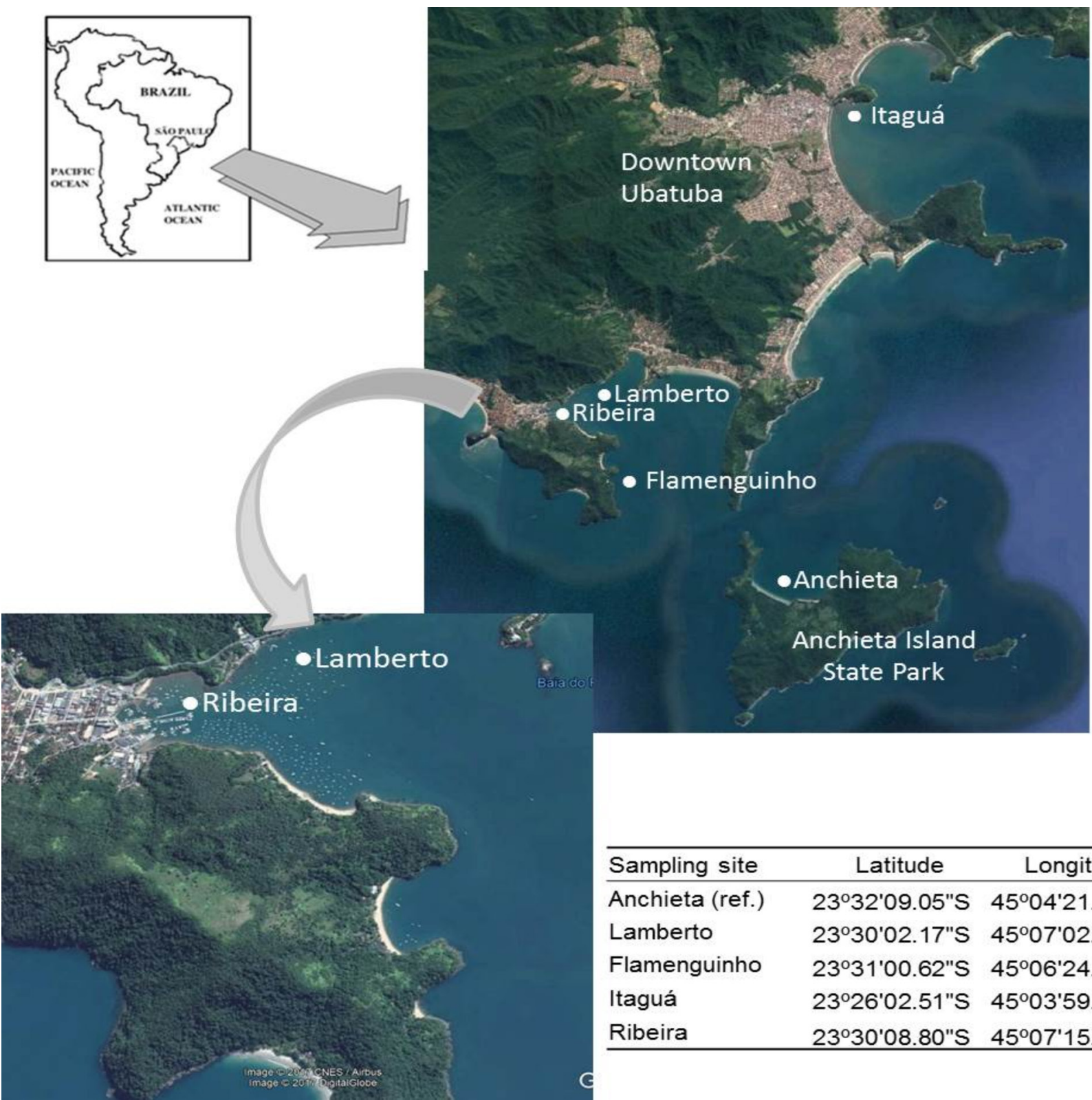

\begin{tabular}{lcc}
\hline Sampling site & Latitude & Longitude \\
\hline Anchieta (ref.) & $23^{\circ} 32^{\prime} 09.05^{\prime S} \mathrm{~S}$ & $45^{\circ} 04^{\prime} 21.15^{\prime \prime} \mathrm{W}$ \\
Lamberto & $23^{\circ} 30^{\prime} 02.17^{\prime S}$ & $45^{\circ} 07^{\prime} 02.80^{\prime \prime} \mathrm{W}$ \\
Flamenguinho & $23^{\circ} 31^{\prime} 00.62 " \mathrm{~S}$ & $45^{\circ} 06^{\prime} 24.64^{\prime \prime} \mathrm{W}$ \\
Itaguá & $23^{\circ} 26^{\prime} 02.51^{\prime \prime} \mathrm{S}$ & $45^{\circ} 03^{\prime} 59.42^{\prime \prime} \mathrm{W}$ \\
Ribeira & $23^{\circ} 30^{\prime} 08.80^{\prime \prime} \mathrm{S}$ & $45^{\circ} 07^{\prime} 15.80^{\prime \prime} \mathrm{W}$ \\
\hline
\end{tabular}

Figure 1. Map of the studied area showing the location of the sampling sites. Extracted from Google Earth. 
have used biomarkers (Bainy et al., 2000), which might be costly or require laboratorial efforts that are normally time consuming. The Neutral Red Retention Time (NRRT) assay has been used in studies concerning to evaluate the lysosomal membrane integrity, which can be used as a broad indicator of exposure to xenobiotics (Moore, 1990; Lowe et al., 1995; Cheung et al., 1997; Zaroni et al., 2001). Basically, it involves exposing blood cells to a colored dye, which is taken up by the lysosomes. Healthy cells retain the dye for more time than damaged cells, in which the dye rapidly leaks out into the cytoplasm. This technique has been used to study the health of field collected organisms (Abessa et al., 2005; Catharino et al., 2014; Maranho et al., 2017) or organisms exposed in laboratory, but to our knowledge no study has exposed directly the blood cells to the contaminants. Thus, the present study aimed to assess the quality of sediments from a tropical shallow region exposed to different pollution sources by using some simple and rapid techniques, including imunoassays for analyzing the levels of PAHs, traditional toxicity tests (wholesediment with amphipods and elutriates with embryos of sea urchins) an adaptation of the NRRT assay, which employed the direct exposure of mussels' hemocytes to sediment elutriates.

\section{MATERIALS AND METHODS}

\section{Sediment Samples}

The sediment samples were collected at five different sites from Ubatuba, North Coast of the State of São Paulo (Fig. 1), in September 2000, by using a Petersen grab sampler. Some sites were located close to potential contamination sources such as sewage, urban drainage and marinas. Stations 1 (Ribeira) and 2 (Lamberto) were situated inside the Flamengo Bay, where several marinas are installed; these sites also receive some contribution of sewage. The Station 3 (Flamenguinho) was located in the same bay, but about $2 \mathrm{~km}$ southwards. The Station 4 (Itaguá) was situated in Ubatuba Bay, under the influence of domestic sewage inputs and a fishing terminal. Sediment from Station 5 was collected at Palmas Beach, in the Anchieta Island Marine State Park, and was used as reference; previous studies showed that sediments from this area are uncontaminated and do not present toxicity (Abessa et al., 2008). After collection, sediment samples were cooled and taken to the laboratory. Subsamples for chemical analyses were taken and frozen at $-20{ }^{\circ} \mathrm{C}$ while those for ecotoxicological evaluation were stored at $4{ }^{\circ} \mathrm{C}$.

Grain size distribution was analyzed by the wet and dry sieving method (McCave \& Syvitski, 1991) and samples were classified following the textural classes of particles (Shepard, 1954; Folk \& Ward, 1957), as sands or muds. The contents of organic matter $(\mathrm{OM})$ in the sediment samples were estimated using the loss by ignition method (Luczak et al. 1997); $5 \mathrm{~g}$ of dry sediment aliquots were separated from each sample and incinerated in a muffle $\left(500^{\circ} \mathrm{C}\right)$ for 4 hours. Organic Matter contents were established by calculating the difference between initial and final weights.

\section{Enzyme-Linked Immunosorbent Assay (ELISA) for determining the concentrations of PAHs}

The concentration of PAHs was determined by the commercially available immunoassay ELISA kit for the carcinogenic PAH (c-PAH) RaPID Assay ${ }^{\circledR}$ (SDI Europe, Alton, UK). RaPID Assays ${ }^{\circledR}$ are tube-based immunoassays where the polyclonal antibodies are immobilized onto paramagnetic particles, being developed based on a competitive heterogeneous ELISA (Fillmann et al., 2007).

Initially, an extraction was performed prior to analysis using the SDI extraction kit for PAHs (SDI Europe, Alton, UK). Ten grams $(10 \mathrm{~g})$ of sediment and $20 \mathrm{~mL}$ of $100 \%$ methanol were added to an extraction jar (with 3 stainless steel ball bearings per jar) and capped. The extraction jar was shaken vigorously for $5 \mathrm{~min}$ and then allowed to settle for $15 \mathrm{~min}$. About $1 \mathrm{~mL}$ of the supernatant was filtered using a filtration plunger fitted with a fiber glass filter. The filtered extracts were diluted 1:50-500 for c-PAH RaPID Assay ${ }^{\circledR}$ with $50 \% \mathrm{v} / \mathrm{v}$ methanol/buffered aqueous solution (SDI diluent). The c-PAH RaPID Assay ${ }^{\circledR}$ was used according to the manufacturer's recommendations. The samples were analyzed in triplicate together with 4 calibration standards. Appropriate amounts of samples or standards, antibody-coated microbeads and enzyme conjugate were mixed and incubated. After washing twice with kit buffer using a magnetic rack to retain the antibodies, substrate (hydrogen peroxide) and chromogen (3,3',5,5'-tetramethylbenzidine) were added and incubated. Stop solution (2 mol L-1 sulphuric acid) was added and the color produced was measured at $450 \mathrm{~nm}$ using an microplate reader. Sample concentrations were calculated using a loglogit standard curve and multiplying results by the appropriate dilution factors. Details of this approach were described by Fillmann et al. (2007).

Analytical results were calculated from a standard curve of $0,0.1,1$ and $5 \mathrm{ng}$ benzo(a)pyrene $\mathrm{mL}^{-1}\left(\mathrm{r}^{2}=-0.997\right.$; slope $=-0.580$; interception $=-0.550$ ) previously prepared for the c-PAH RaPID Assay ${ }^{\circledR}$. Then, the concentrations in each sample were calculated by multiplying results by the appropriate dilution factor. As the c-PAH RaPID Assay® was developed using benzo(a)pyrene as the reference molecule, the compositions of the environmental extracts indicate a "quantitative" measure of benzo(a)pyrene "equivalents".

Soxhlet extracted dry sediments $(10 \mathrm{~g})$ were fortified with the PAH standard mixture solution (SRM 1491) prepared in hexane, purchased from Promochem (Herts, UK). Fortified sediment samples were left to stabilize for $6 \mathrm{~h}$ before extraction.

\section{Sediment elutriate toxicity test}

The sediment elutriates were obtained by mixing a composite sediment sample and filtered clean seawater in the 1:4 ratio (USEPA, 1991), followed of an overnight resting period, allowing to the particles to settle and finally pipetting the elutriates. The elutriate samples were evaluated 
by the early life stage bioassay with embryos of the sea urchin Lytechinus variegatus (CETESB, 1992). In the beginning of the test, the salinity, $\mathrm{pH}$, dissolved oxygen and temperature of the elutriates were checked. The total ammonia concentration was measured by a colorimetric method (Koroleff, 1970). Using these data, the unionized ammonia contents were estimated, using the method reported by Whitfield (1974).

Prior to the beginning of the test, adult individuals of $L$. variegatus were collected from a clean site at Ubatuba, and taken to the laboratory. The spawning was induced by the injection of 2-3 mL of $\mathrm{KCl}$ into the coelomic cavities of the animals, and gametes of 3 males and 3 females were collected. Ovules were collected by precipitation in beakers filled with filtered seawater, whereas the sperm was collected dry and transferred to beakers kept on ice. The sperm was activated by dilution in filtered seawater and the ovules were fertilized by adding $2 \mathrm{~mL}$ sperm solution to the eggs solution. The fertilization success was confirmed by examination under the microscope. The toxicity test was conducted in glass test tubes containing $10 \mathrm{~mL}$ test-solution. Four replicates were used for each sample. Only $100 \%$ elutriate samples were prepared and tested. The experiment was kept in a temperature controlled room, at $25 \pm 2{ }^{\circ} \mathrm{C}$. After $24 \mathrm{~h}$, the test was stopped by adding $0.75 \mathrm{~mL}$ of $10 \%$ buffered formaldehyde to each replicate. The embryos were analyzed microscopically for morphological anomalies and retarded development (100 per replicate). All the embryos which did not reach a well-developed pluteus larvae were considered affected.

\section{Whole sediment toxicity test}

Whole sediment acute toxicity tests were conducted using the amphipod Tiburonella viscana, as described by Melo \& Abessa (2002). Five replicates per test sediment were prepared. One day before the beginning of the test, each sediment sample was thoroughly homogenized and aliquots were distributed into the test chambers (1-L polyethylene beakers). The test chambers were filled with $2 \mathrm{~cm}$ depth with the test sediments and filtered seawater up to $750 \mathrm{~mL}$, and then maintained overnight at $25 \pm 2{ }^{\circ} \mathrm{C}$ with gentle aeration (maintained by air pumping). On the next day, 10 amphipods were added to each test chamber. The tests were conducted at $25 \pm 2{ }^{\circ} \mathrm{C}$, under constant aeration and lighting. After ten days, the contents of the test-chambers were gently sieved through a $0.5-\mathrm{mm}$ screen and the surviving amphipods were counted. Missing organisms were considered dead. Mortalities were compared with that of the reference sediment by Student t'test. The dissolved oxygen concentration, salinity and $\mathrm{pH}$ of the overlying water in the test chambers were measured at the beginning and end of the tests. The water temperature was monitored daily.

\section{Neutral Red Retention Time Assay}

In the present investigation, the Neutral Red Retention Time (NRRT) assay consisted in exposing hemocytes of the mussel Perna perna directly to sediment elutriates. Adult mussels were collected from a clean site at Ponta Grossa, Ubatuba (Zaroni et al., 2001). They were taken to laboratory and immediately used. Perna perna is commonly used in experiments regarding biomarkers and bioaccumulation (Bainy et al., 2000; Zaroni et al., 2001; Ferreira et al., 2000) and there is a protocol for employing its hemocytes in studies using the NRRT assay (Abessa et al., 2005). For this study, 20 animals were used per treatment.

Prior to the beginning of the experiment, a physiological saline solution was prepared as described by Moore (1990), and the elutriates were prepared by adding $50 \mathrm{~mL}$ of each sediment sample into $150 \mathrm{~mL}$ physiological saline (1:4 proportion) and agitating for $30 \mathrm{~min}$ at speed or rpm (Burton, 1992). After mixing, each elutriate was left decanting overnight and the supernatants were exposed to the mussels' hemocytes.

The assays were conducted at $25 \pm 2{ }^{\circ} \mathrm{C}$. Initially, $0.2 \mathrm{~mL}$ hemolymph was collected from the posterior adductor muscle of each mussel, with syringes containing $0.2 \mathrm{~mL}$ elutriate, and transferred to an Eppendorf tube. Then, $40 \mu \mathrm{L}$ of the hemocyte cells solution was pipetted and dropped onto a glass slide. The slides were placed into a dark and humid chamber and incubated for $15 \mathrm{~min}$. During this interval, the NR working solution was prepared by the dilution of $10 \mu \mathrm{L}$ previously prepared stock solution with $5 \mathrm{~mL}$ physiological saline solution. After incubation, $40 \mu \mathrm{L}$ of NR working solution was dropped onto each slide. At the end of $15 \mathrm{~min}$, the slides were quickly examined by microscopy. The cells were observed for structural abnormalities and for the retention time of the NR dye. The cell conditions were analyzed and recorded at 15 min intervals, until the majority of the cells were considered affected (i.e., if the dye was released to the cytosol; presence of vacuoles; modified cell shape; loss of fluids), as recommended by the protocols (Moore, 1990; Lowe et al., 1995).

\section{Statistical Analyses}

The results of the ecotoxicological assays were statistically analyzed by the student t-test (Zar, 1996), for comparison of the respective endpoints between the reference site (Anchieta) and the other tested sediments. The results were also compared by Spearman correlations, in order to find any relationship between the toxicity and the sediment properties.

\section{RESULTS AND DISCUSSION}

The texture of sediment samples ranged from sandy (Anchieta and Lamberto) to muddy sands (Itaguá and Ribeira) and sandy muds (Flamenguinho) (Table 1); besides, all the samples presented relatively low levels of organic matter (from 2.1 to $6.3 \%$ ). The concentrations of PAHs measured by the ELISA (expressed in $\mathrm{BaP}$ equivalents) showed relatively higher concentrations in the sediments from Ribeira and Itaguá (Table 1). No significant relationships were found between PAH levels and mud or OM contents ( $p$ $>0.05$ ). Despite reasonable PAH contamination were found in sediments of Ribeira (104 (BaP equiv) $\mathrm{ng} \mathrm{g}^{-1}$ ) and Itaguá 
(88.2 (BaP equiv) $\mathrm{ng} \mathrm{g}^{-1}$ ), levels are lower in comparison to other more contaminated coastal areas of Brazil (i.e. Rio Grande Harbor, Patos Lagoon Estuary - Fillmann et al., 2007). That was expected since Ribeira is under direct influence of sewage, stormwater and especially marinas, whereas Itaguá is under influence of similar sources (mainly sewage and stormwater). Marinas (King et al., 2004; Neira et al., 2017), sewage (Nichols \& Espey, 1991; Wlodarczyk-Makula, 2005; Gasperi et al., 2012) and stormwaters (Launay et al., 2016; Rogers, 2002) have been identified as local sources of PAHs. In addition, Itaguá waters are often considered by the State Environmental Agency as of poor quality for bathing (CETESB, 2008, 2013, 2016).

Results of the toxicity tests with elutriates and wholesediments are shown in Figure 2. In general, physicochemical parameters were considered within the appropriate ranges for the species tested (see the Supplementary Material). Elutriates obtained from the Flamenguinho and Itaguá sediments caused significant effects on the embryolarval development of L. variegatus (Figure 2), although the toxicity related to Flamenguinho elutriate could have been influenced by the unionized ammonia, since the level found $\left(0.14 \mathrm{mg} \mathrm{L}^{-1}\right)$ exceeded the toxic threshold to embryos of $L$. variegatus $(0.05$ $\mathrm{mg} \mathrm{L}^{-1}$ ); this sediment also presented the highest amount of mud (65.9\%) and the lowest levels of PAHs. Regarding the whole sediment tests, the samples from Lamberto and Ribeira showed to be toxic to the amphipods (Figure 2). No correlation was seen between toxicity and either PAHs concentrations or sediment textures, although Ribeira presented the highest concentration of PAHs $(\mathrm{p}>0.05)$.

The NRRT assay showed significant effects in hemocytes exposed to elutriates of Itaguá, Ribeira and Lamberto (Figure 3 ), despite the high variation between replicates. In this study, the concentrations of contaminants in the elutriates were not measured, but the results suggest that part of the substances from the sediment were transferred to the elutriates. The NRRT reduction correlated with the concentrations of PAHs $\left(r^{2}=-0.86 ; p<0.05\right)$. In fact, the lower NRRT was observed in cells exposed to elutriates from Ribeira, where the highest concentration of PAH was found. Polycyclic aromatic hydrocarbons are known for causing several types of negative effects on aquatic organisms (Bihari et al., 2006; 2007) and considered highly toxic (Driscoll et al., 1998; Fishelson et al., 1999) and carcinogenic (Yu, 2002).

The results showed a worse condition in Itaguá and the internal portion of Ribeira Bay (Ribeira and Lamberto stations), where sediment toxicity and relatively higher levels PAHs were observed. As mentioned, Ribeira and Lamberto are located in a zone of marinas, where other contaminants, such as metals, antifouling biocides and other contaminants of emerging concern, are expected to occur. In fact, Godoi (2001) detected organotins, while metals (As, $\mathrm{Cu}, \mathrm{Pb}, \mathrm{Hg}, \mathrm{Zn}$ ) and sediment toxicity have been systematically observed in sediments of Ribeira Bay (CETESB, 2008; 2013, 2016). The
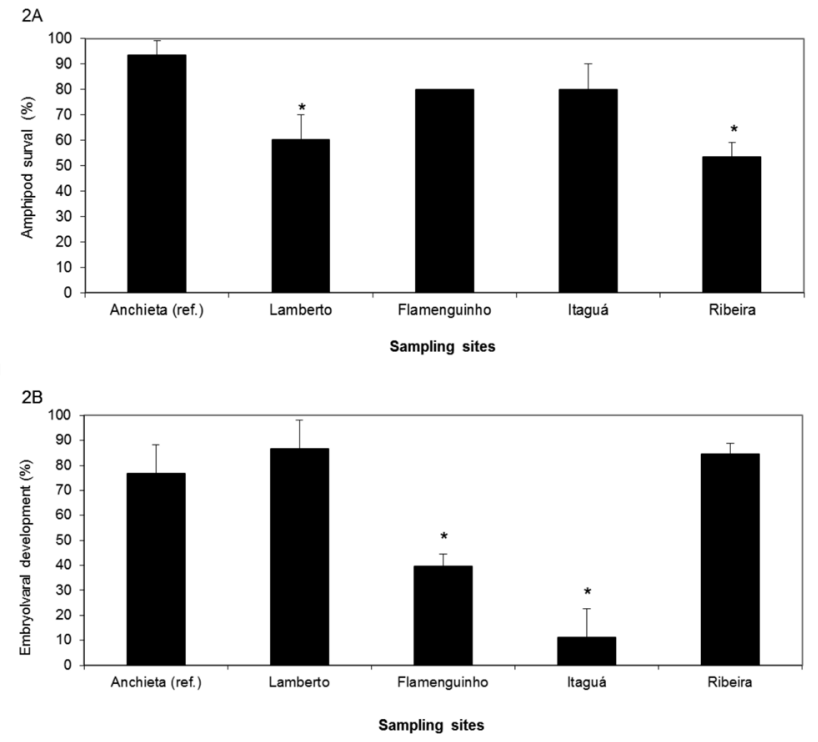

Figure 2. Toxicity of sediments from some sites of Ubatuba, SP, Brazil. A) Whole-sediment toxicity to the amphipod Tiburonella viscana; B) Elutriate toxicity to embryos of the sea-urchin Lytechinus variegatus. Data are presented as means \pm standard deviations. $*$ indicates significant differences to the reference (Anchieta), at $\mathrm{p}<0.05$.

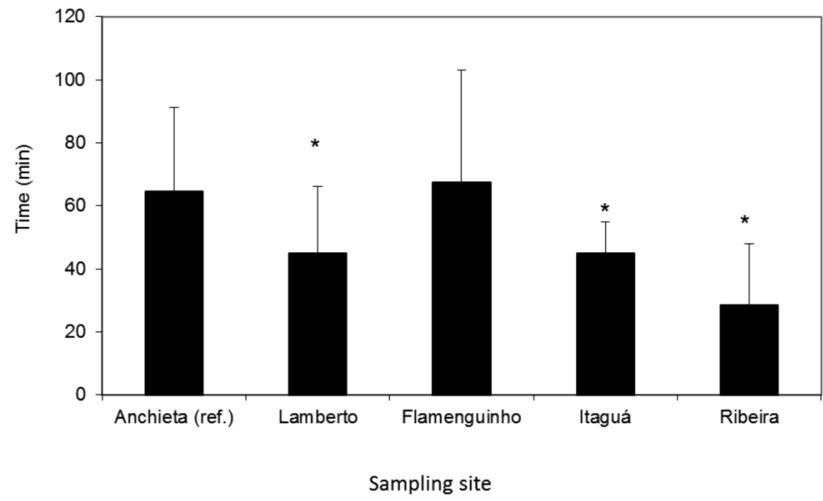

Figure 3. Neutral Red Retention Time in hemocytes of Perna perna exposed to elutriates prepared from sediments of Ubatuba. Data are presented as means \pm standard deviations. * indicates significant differences to the reference (Anchieta), at $\mathrm{p}<0.05$.

Table 1. Texture, Organic Matter contents (\%) and PAH levels (benzo(a)pyrene “equivalents", ng $^{-1}$ ) in the sediments from Ubatuba (southeastern Brazil).

\begin{tabular}{lcccccc}
\hline Sediment sample & Sand (\%) & Mud (\%) & Organic Matter (\%) & Classification & $\begin{array}{c}\text { PAHs by ELISA (BaP equiv. ng } \\
\left.\mathrm{g}^{-1}\right)\end{array}$ \\
\hline Anchieta (ref.) & 98.3 & 1.7 & 6.3 & Sand & Sand & 16.3 \\
Lamberto & 88.2 & 11.8 & 5.4 & Sandy muds & 23.5 & 1.0 \\
Flamenguinho & 34.1 & 65.9 & 2.1 & Muddy sands & 88.2 \\
Itaguá & 73.7 & 26.3 & 6.3 & Muddy sands & 104.2 \\
Ribeira & 55.6 & 44.4 & 4.7 & & \\
\hline
\end{tabular}


results obtained to Flamenguinho indicate low contamination and a toxicity caused by natural levels of unionize ammonia. On the other hand, the results confirmed Ilha Anchieta as a less contaminated and non-toxic (under the tested conditions) environment, corroborating with official data (CETESB, 2007) and confirming that protected areas can provide better conditions of conservation.

The adaptation of NRRT assay for directly exposing sediment samples elutriate to mussel hemocytes showed to be viable and produced reliable results. Results showed good correspondence with classic toxicity test, and even better with the results of PAH contamination. Moreover, it has been a cost-effective, rapid and sensitive tool for evaluating toxicity of marine sediments. This technique can be used in environmental surveys, especially as a screening step whenever a lot of samples have to be scanned in order to identify hot spots. The results also showed that Ribeira Bay and Itaguá present signs of environmental degradation, requiring further efforts to diagnose the contamination levels and their effects and risks to the local biota.

\section{ACKNOWLEDGEMENTS}

This research was part of the Rapid Assessment of Marine Pollution (RAMP) programme funded by a DFID-UK (Department for International Development) grant to M.H. Depledge and J.W. Readman and by the ODA (Overseas Development Administration). Denis Abessa and Marcia Bícego were fellows of $\mathrm{CNPq}$ and Gilberto Fillmann was fellow of CAPES.

\section{REFERENCES}

ABESSA, D.M.S., ZARONI, L.P., SOUSA, E.C.P.M., GASPARRO, M.R., PEREIRA, C.D.S., RACHID, B.R.F., DEPLEDGE, M. \& KING, R.S. 2005. Physiological and cellular responses in two populations of the mussel Perna perna collected at different sites from the coast of São Paulo, Brazil. Braz. Arch. Biol. Technol., 48(2): 217-225. https://dx.doi.org/10.1590/S151689132005000200008

ABESSA, D.M.S., SOUSA, E.C.P.M. \& TOMMASI, L.R. 2006. Utilização de testes de toxicidade na avaliação da qualidade de sedimentos marinhos. Rev Geologia, 19(2): 253-261.

ABESSA, D.M.S., CARR, R.S., SOUSA, E.C.P.M., RACHID, B.R.F., ZARONI, L.P., PINTO, Y.A., GASPARRO, M.R., BÍCEGO, M.C., HORTELLANI, M.A., SARKIS, J.E.S. \& MUNIZ, P. 2008. Integrative Ecotoxicological Assessment of a Complex Tropical Estuarine System. In: Hoffer, T.N. (ed) Marine Pollution: New Research. New York, Nova Science Publishers Inc., Chapter 4, pp.125-159.

ABNT - Associação Brasileira de Normas Técnicas, 2008. ABNT/ NBR 15638. Qualidade da Água: Determinação da toxicidade aguda de sedimentos marinhos ou estuarinos com anfípodos (17 pp.).

ABNT - Associação Brasileira de Normas e Técnicas, 2012. ABNT/NBR 15350. Ecotoxicologia aquática: Toxicidade crônica de curta duração - Método de ensaio com ouriço do mar (Echinodermata: Echinoidea) (21 pp.).

ARAÚJO-CASTRO, C.M.W., SOUZA-SANTOS, L.P.,
TORREIRO, A.G.A.G. \& GARCIA, K.S. 2009. Sensitivity of the marine benthic copepod Tisbe biminiennsis (Copepoda, Harpacticoida) to Potassium Dichromate and sediment particle size. Braz. J. Oceanogr., 57(1): 33-41. http://dx.doi.org/10.1590/ S1679-87592009000100004

BAINY, A.C.D., ALMEIDA, E.A., MULLER, I.C., VENTURA, E.C. \& MEDEIROS, I.D. 2000. Biochemical responses in farmed mussel Perna perna transplanted to contaminated sites on Santa Catarina Island, SC, Brazil. Mar. Environ. Res., 50: 411-416.

BIHARI, N., FAFANDEL, M., HAMER, B. \& KRALJ-BILEN, B. 2006. PAH content, toxicity and genotoxicity of coastal marine sediments from the Rovinj area, Northern Adriatic, Croatia. Sci Total Environ., 366(2-3): 602-611 https://doi.org/10.1016/j. scitotenv.2005.12.001

BIHARI, N., FAFANDEL, M. \& PISKUR, V. 2007. Polycyclic aromatic hydrocarbons and ecotoxicological characterization of seawater, sediment, and mussel Mytilus galloprovincialis from the Gulf of Rijeka, the Adriatic Sea, Croatia. Arch Environ Contam Toxicol, 52(3): 379-87. https://doi.org/10.1007/s00244005-0259-5

BURTON Jr., G.A. 1992. Assessing contaminated aquatic sediments. Environ. Sci. Technol. 26: 1862-1875. http://dx.doi.org/10.1021/ es00034a613

CATHARINO, M.G.M., VASCONCELLOS, M.B.A., KIRSCHBAUM, A.A., GASPARRO, M.R., SOUSA, E.C.P.M., MINEI, C.C. \& MOREIRA, E.G. 2014. Passive biomonitoring study and effect biomarker in oysters Crassostrea brasiliana (Lamark, 1819: Mollusca, Bivalvia) in Santos and Cananéia Estuaries in São Paulo State, Brazil. J. Radioanalytical and Nuclear Chem., 303: 2297-2302. http://dx.doi.org/10.1007/ s10967-014-3720-y

CETESB. 1992. Água do mar - Teste de toxicidade crônica de curta duração com Lytechinus variegatus Lamarck, 1816 (Echinodermata: Echinoidea). Norma Técnica L5.250. CETESB, São Paulo, 16p.

CETESB. 2008. Relatório de qualidade das águas litorâneas do estado de São Paulo 2007. CETESB, São Paulo, 294 p.

CETESB. 2013. Qualidade das águas salinas e salobras no Estado de São Paulo: $2^{\mathrm{a}}$ parte do relatório de águas superficiais. Série Relatórios. CETESB, São Paulo, 434p.

CETESB. 2016. Qualidade das águas superficiais no estado de São Paulo 2015. Série Relatórios, CETESB, São Paulo, 562p. (2 arquivos de texto)

CHAPMAN, P.M. \& HOLLERT, H. 2006. Should the Sediment Quality Triad become a Tetrad, a Pentad, or possibly even a Hexad? J. Soils Sediments, 6(1): 4-8. https://doi.org/10.1065/ jss2006.01.152

CHEUNG, V.V., WEDDERBURN, R.J. \& DEPLEDGE, M.H. 1997. Molluscan lysosomal responses as a diagnostic tool for the detection of a pollution gradient in Tolo Harbor, Hong Kong. Mar. Environ. Res., 46: 273-241. https://doi.org/10.1016/S01411136(97)00104-9

CRUZ, A.C.F. 2014. Using chemical and ecotoxicological approaches to assess the ecological risk of pollutants in the Cananeia-Iguape Estuarine Complex, SP, Brazil. Master of Science Dissertation. Universidade de São Paulo, Instituto Oceanográfico, 67p + appendices.

FERREIRA, A.G., MACHADO, A.L.S. \& ZALMON, I.R. 2000. Metais Pesados em moluscos no litoral norte do Rio de Janeiro. In: Espíndola, E.L.G., Botta-Paschoal, C.M.R., Rocha, O., Bohrer, M.B.C. \& Neto, A.L.O. (Eds.). Ecotoxicologia: Perspectivas para o Século XXI. São Carlos, SP. Rima, pp. 167-182.

FILLMANN, G., BICEGO, M.C., ZAMBONI, A., FILEMAN, T.W., DEPLEDGE, M.H. \& READMAN, J.W. 2007. Validation of 
immunoassay methods to determine hydrocarbon contamination in estuarine sediments. J. Brazil. Chem. Soc., 18(4): 774-781. https://dx.doi.org/10.1590/S0103-50532007000400016

FOLK, R.L. \& WARD, W.C. 1957. Brazon River bar: a study in the significance of grain size parameters. J. Sediment Petrol., 27(1): 3-27. http://dx.doi.org/10.1306/74D70646-2B21-11D78648000102C1865D

GALLOWAY, T.; SANGER, R.C.; SMITH, K.L.; FILLMANN, G.; READMAN, J.W.; FORD, T.E. \& DEPLEDGE, M.H. 2002. Rapid Assessment of Marine Pollution Using Multiple Biomarkers and Chemical Immunoassays. Environ. Sci. Technol. 36, 2219-2226

GASPERI, J., ZGHEIB, S, CLADIÈRE, M., ROCHER, V., MOILLERON R. \& CHEBBO, G. 2012. Priority pollutants in urban stormwater: part 2 - case of combined sewers. Water Res., 46(20): 6693-6703. https://doi.org/10.1016/j.watres.2011.09.041

GODOI, A.F.L. 2001. Estudos sobre a ocorrência de compostos organoestânicos em sedimentos marinhos superficiais na costa do estado de São Paulo. 2001. 131 p. Tese (doutorado) Universidade Estadual Paulista, Instituto de Química. Available at https://repositorio.unesp.br/handle/11449/105669?show=full

KING, A.J., READMAN, J.W. \& ZHOU, J.L. 2004. Dynamic behaviour of polycyclic aromatic hydrocarbons in Brighton marina, UK. Mar Pollut Bull., 48(3-4): 229-39. https://doi. org/10.1016/S0025-326X(03)00393-X

KOROLEFF, F. 1970. Direct determination of ammonia in natural waters as indophenol blue. Information on techniques and methods for seawater analysis, Interlab. Rep. Cons. int. Explor. Mer., 3: 19-22.

LAUNAY, M.A., DITTMER, U. \& STEINMETZ, H. 2016. Organic micropollutants discharged by combined sewer overflows Characterisation of pollutant sources and stormwater - related processes. Water Res., 104: 82-92. https://doi.org/10.1016/j. watres.2016.07.068

LOTUFO, G.R. \& ABESSA, D.M.S. 2002. Testes de toxicidade com sedimentos total e água intersticial estuarinos utilizando copépodos bentônicos. In: Nascimento, I.A., Sousa, E.C.P.M., Nipper, M.G. (Eds.), Métodos em Ecotoxicologia Marinha: Aplicações no Brasil cap. 13. Artes Gráficas e Indústria Ltda, São Paulo, pp. 151-162.

LOWE, D.M., FOSSATO, V.U. \& DEPLEDGE, M.H. 1995. Contaminant induced lysosomal membrane damage in blood cells of mussels Mytilus galloprovincialis from Venice Lagoon: an in vitro study. Mar. Ecol. Progr. Ser., 129: 189-196. http:// dx.doi.org/10.3354/meps 129189

LUCZAK, C., JANQUIN, M.A. \& KUPKA, A. 1997. Simple standard procedures for the routine determination of organic matter in marine sediment. Hydrobiologia, 345: 87-94.

MELO, S.L.R., \& ABESSA, D.M.S. 2002. Testes de toxicidade com sedimentos marinhos utilizando anfípodos como organismoteste. In: Nascimento, I., Sousa, E.C.P.M. \& Nipper, M.G. (eds). Ecotoxicologia Marinha: Aplicações no Brasil. Salvador/BA, Brasil: Editora Artes Gráficas, pp. 163-178.

MOLISANI, M.M., COSTA, R.N., CUNHA, P., DE REZENDE, C.E., FERREIRA, M.I. \& DE ASSIS ESTEVES, F. 2013. Acute toxicity bioassay with the amphipod, Grandidierella bonnieroides S. after exposure to sediments from an urban estuary (Macaé River Estuary, RJ, Brazil). Bull Environ Contam Toxicol. 90(1): 79-84. https://doi.org/10.1007/s00128-012-0871-9

MOORE, M.N. 1990. Lysosomal cytochemistry in marine environmental monitoring. Histochem, J., 22: 189-191. https:// doi.org/10.1007/BF02386003

NEIRA, C., COSSABOON, J., MENDOZA, G., HOH, E. \& LEVIN, L.A. 2017. Occurrence and distribution of polycyclic aromatic hydrocarbons in surface sediments of San Diego Bay marinas. Mar Pollut Bull., 114(1): 466-479. https://doi.org/10.1016/j. marpolbul.2016.10.009

NICHOLS, P.D. \& ESPEY, Q.I. 1991. Characterization of organic matter at the air-sea interface, in subsurface water, and in bottom sediments near the Malabar sewage outfall in Sydney's coastal region. Australian J. Mar and Freshwater Res., 42(4): 327-348. https://doi.org/10.1071/MF9910327

NIPPER, M.G., GREENSTEIN, D.J. \& BAY, S.M. 1989. Short and long-term sediment toxicity test methods with the amphipod Grandidierella japonica. Environ. Toxicol. Chem., 8: 11911200. http://dx.doi.org/10.1002/etc.5620081212

MARANHO, L.A., FONTES, M.K., KAMIMURA, A.S.S., NOBRE, C.R., MORENO, B.B., PUSCEDDU, F.H., CORTEZ, F.S., LEBRE, D.T., MARQUES, J.R., ABESSA, D.M.S., RIBEIRO, D.A. \& PEREIRA, C.D.S. 2017. Exposure to crack cocaine causes adverse effects on marine mussels Perna perna. Mar. Pollut. Bull., 123(1-2): 410-414. https://doi.org/10.1016/j. marpolbul.2017.08.043

MCCAVE I.N., SYVITSKI J.P.M. 1991. Principles and methods of geological particle size analysis. In: J.P.M. Syvitski (ed.). Principles, Methods, and Application of Particle Size Analysis, Cambridge University Press, Cambridge. pp. 3-21.

ROGERS, H.R. 2002. Assessment of PAH contamination in estuarine sediments using the equilibrium partitioning-toxic unit approach. Sci Total Environ., 290(1-3): 139-155. https://doi. org/10.1016/S0048-9697(01)01079-8

SHEPARD, F.P. 1954. Nomenclature based on sand silt-clay ratios. J. Sediment Petrol., 24: 151-158. https://doi.org/10.1306/ D4269774-2B26-11D7-8648000102C1865D

SWARTZ, R.C., DEBEN, W.A., JONES, J.K.P., LAMBERSON, J.O. \& COLE, F.A. 1985. Phoxocephalid amphipod bioassay for marine sediment toxicity. 7. Symposium on Aquatic Toxicology and Hazard Assessment, Philadelphia, ASTM, 284-307.

USEPA - United States Environmental Protection Agency. 1991. Evaluation of Dredged Material Proposed for Ocean Disposal - testing manual. U.S. Army Corps of Engineers, EPA 503/891/001, 214p.

WHITFIELD, M. 1974. The hydrolysis of ammonia ions in sea water - a theoretical study. J. Mar. Biol. Assoc. U.K., 54: 565-580. https://doi.org/10.1017/S002531540002275X

WLODARCZYK-MAKULA, M. 2005. The loads of PAHs in wastewater and sewage sludge of municipal treatment plant. Polycycl. Aromat. Comp., 25(2): 183-194. https://doi. org/10.1080/10406630590930743

YU, H. 2002. Environmental carcinogenic polycyclic aromatic hydrocarbons: photochemistry and phototoxicity. J Environ Sci Health CEnviron Carcinog Ecotoxicol Rev., 20(2): 10.1081/GNC120016203. https://dx.doi.org/10.1081\%2FGNC-120016203

ZAMBONI, A. J. \& COSTA, J. B. 2002. Testes de toxicidade com sedimentos marinhos utilizando Tanaidáceos, In: Nascimento, I.A., Sousa, E.C.P.M. \& Nipper, M.G. (eds,). Métodos em Ecotoxicologia Marinha: Aplicações no Brasil. São Paulo, SP. Artes Gráficas e Indústria. pp.123-178p

ZAR, J.H., 1996. Biostatistical analysis, 3rd ed. Nova Jersey, USA: Prentice-Hall, 662p.

ZARONI, L.P., ABESSA, D.M.S., RACHID, B.R.F. \& SOUSA, E.C.P.M. 2001. Diferenças no estado fisiológico de adultos e na viabilidade de embriões do mexilhão Perna perna provenientes de duas populações coletadas em Ubatuba - SP. In: Moraes, R., Crapez, M., Pfeiffer, W., Farina, M., Bainy, A. \& Teixeira, V. Efeitos de Poluentes sobre Organismos Marinhos. São Paulo: Arte \& Ciência Villipres. pp. 15-25. 


\section{SUPPLEMENTARY MATERIAL}

S1. Physicochemical variables of the overlying water during the whole-sediment toxicity test with the amphipod Tiburonella viscana and samples from Ubatuba (SP, Brazil).

\begin{tabular}{lcccccc}
\hline & \multicolumn{2}{c}{ Salinity } & \multicolumn{2}{c}{ Dissolved Oxygen $\left(\mathrm{mg} . \mathrm{L}^{-1}\right)$} & \multicolumn{2}{c}{$\mathrm{pH}$} \\
\hline & Initial & Final & Initial & Final & Initial & Final \\
\hline Anchieta (ref.) & 33 & 34 & 5.45 & 5.67 & 8.1 & 8.0 \\
Lamberto & 34 & 34 & 4.88 & 4.92 & 8.2 & 8.0 \\
Flamenguinho & 34 & 35 & 4.97 & 5.17 & 8.1 & 8.1 \\
Itaguá & 33 & 34 & 4.33 & 5.25 & 8.1 & 8.1 \\
Ribeira & 34 & 34 & 4.08 & 4.76 & 8.1 & 8.2 \\
\hline
\end{tabular}

S2. Physicochemical variables of sediment elutriates during the toxicity test with the embryos of the sea urchin Lytechinus variegatus and samples from Ubatuba (SP, Brazil). Dilutions were made in filtered sweater.

\begin{tabular}{lcccc}
\hline & Salinity & $\begin{array}{c}\text { Dissolved Oxygen } \\
\left(\mathrm{mg} . \mathrm{L}^{-1}\right)\end{array}$ & $\mathrm{pH}$ & $\mathrm{NH}_{3}\left(\mathrm{mg} . \mathrm{L}^{-1}\right)$ \\
\hline Anchieta (ref.) & 34 & 5.65 & 8.2 & 0.02 \\
Lamberto & 34 & 5.02 & 8.2 & 0.04 \\
Flamenguinho & 34 & 5.39 & 8.1 & 0.14 \\
Itaguá & 35 & 4.97 & 7.9 & 0.04 \\
Ribeira & 34 & 4.83 & 7.9 & 0.04 \\
\hline
\end{tabular}

S3. Physicochemical variables of sediment elutriates during the Neutral Red Retention Time assay using hemocytes of the brown mussel Perna perna and samples from Ubatuba (SP, Brazil). Dilutions were made in saline physiological solution.

\begin{tabular}{lcccc}
\hline & Salinity & $\begin{array}{c}\text { Dissolved Oxygen } \\
\left(\mathrm{mg} . \mathrm{L}^{-1}\right)\end{array}$ & $\mathrm{pH}$ & $\mathrm{NH}_{3}\left(\mathrm{mg} . \mathrm{L}^{-1}\right)$ \\
\hline Anchieta (ref.) & 33 & 5.2 & 7.3 & $<0.01$ \\
Lamberto & 33 & 5.2 & 7.5 & 0.05 \\
Flamenguinho & 33 & 5.1 & 7.3 & 0.11 \\
Itaguá & 33 & 5.0 & 7.4 & 0.06 \\
Ribeira & 33 & 5.0 & 7.4 & 0.05 \\
\hline
\end{tabular}

